\title{
FAKTOR-FAKTOR YANG BERHUBUNGAN DENGAN STATUS GIZI BALITA
}

\author{
Boediarsih $^{1}$, Wahyu Wiedy Aditantri ${ }^{2}$, Dwi Kustriyanti ${ }^{3}$ \\ 1,2,3 STIKes Karya Husada Semarang \\ Email: boediarsih@yahoo.com
}

\begin{abstract}
ABSTRAK
Status gizi balita ( bawah lima tahun ) merupakan gambaran kesehatan mengenai konsumsi pangan dan penggunaannya oleh tubuh pada usia dibawah lima tahun. Status gizi dipengaruhi oleh beberapa faktor yaitu langsung, tidak langsung dan mendasar. Untuk mengetahui hubungan pola asuh makan, tingkat pendidikan, pengetahuan ibu dan pendapatan keluarga dengan status gizi balita. Jenis penelitian ini adalah penelitian kuantitatif korelasional dengan pendekatan cross sectional. Populasi balita di Puskesmas Poncol sejumlah 1312 balita. Teknik pengambilan sampel dalam penelitian ini menggunakan proportional stratified random sampling dengan sampel sebanyak 89 responden di Puskesmas Poncol Kota Semarang. Analisa menggunakan Kolmogorov Smirnov.

Faktor yang berhubungan dengan status gizi yaitu pola asuh makan ( $\mathrm{p}$ value $=0,411)$, tingkat pendidikan ( $\mathrm{p}$ value $=0,018)$, pengetahuan $\mathrm{ibu}(\mathrm{p}$ value $=0,062)$, pendapatan keluarga ( $\mathrm{p}$ value $=0,000$ ). Tidak ada hubungan pola asuh makan, pengetahuan ibu dengan status gizi. Ada hubungan tingkat pendidikan, pendapatan keluarga dengan status gizi. Maka dari itu perlunya mengoptimalkan program pemantauan status gizi balita dan meningkatkan pengetahuan gizi masyarakat
\end{abstract}

Kata kunci: Balita 


\title{
FACTORS THAT ARE RELATED TO THE NUTRITIONAL STATUS OF CHILDREN
}

\begin{abstract}
Toddler nutritional status (under five years) is a picture of health regarding food consumption and use by the body at the age of under five years. Nutritional status is influenced by several factors, namely direct, indirect and fundamental. To determine the relationship between parenting, education level, mother's knowledge and family income with the nutritional status of toddlers. This type of research is correlational quantitative research with cross sectional approach. The population of children under five in the Poncol Health Center is 1312 children under five. The sampling technique in this study used proportional stratified random sampling with a sample of 89 respondents in Poncol Health Center, Semarang City. Analysis using Kolmogorov Smirnov.

Factors related to nutritional status are parenting ( $p$ value $=0.411)$, education level $(p$ value $=0.018)$, mother's knowledge ( $p$ value $=0.062)$, family income $(p$ value $=0.000)$. There is no relationship between parenting, mother's knowledge and nutritional status. There is a relationship between education level, family income and nutritional status. Therefore it is necessary to optimize the nutritional status monitoring program for toddlers and increase community nutrition knowledge
\end{abstract}

Keywords: Toddler 


\section{LATAR BELAKANG}

Balita adalah anak yang telah menginjak usia di atas satu tahun atau di bawah lima tahun yaitu 24-60 bulan (Kemenkes RI, 2015). Masa ini menjadi tantangan bagi orang tua karena anak susah makan, memilih makan dan suka pada jajan yang kandungan gizinya tidak baik seperti mie instant, sehingga menyebabkan kekurangan atau kelebihan asupan zat gizi yang dapat mempengaruhi status gizi dan kesehatannya (Setyawati \& Hartini, 2018).

Masalah gizi merupakan masalah global yang terjadi di sebagian besar belahan dunia. WHO 2018 menyatakan pada tahun 2017 di dunia sekitar 22,2 \% atau 150,8 juta balita mengalami stunting, $7,5 \%$ atau 50,5 juta balita mengalami wasting dan $5,6 \%$ atau 38,3 juta balita mengalami overweight (World Health Organization, 2018). Berdasarkan hasil survei pendahuluan di Puskesmas Poncol yang dilakukan pada 10 balita yang mengalami gizi buruk, membuktikan bahwa persentase ibu yang kurang paham pola asuh pemberian makan sebesar 60\%, pengetahuan ibu tentang gizi balita rendah sebesar $60 \%$, tingkat pendidikan ibu yang rendah sebesar $70 \%$, serta pendapatan keluarga rendah sebesar $80 \%$.

Angka kejadian gizi buruk tidak terlepas dari faktor-faktor yang mempengaruhi seperti tingkat pendidikan orang tua, pengetahuan, pola asuh dan pendapatan keluarga (Septikasari, 2018). Penelitian Afritayeni dinyatakan bahwa pola pemberian makan pada balita yang mengalami gizi buruk tidak baik (Afritayeni, 2017).

Penelitian Indah dan Jayani menunjukkan hubungan antara infeksi dengan status gizi balita di Puskesmas
Jambon Kecamatan Jambon Kabupaten Ponorogo (Indah \& Jayani, 2015). Penelitian Nyndina Puspasari menunjukkan bahwa sebagian besar ibu balita memiliki pengetahuan tentang gizi yang baik dengan status gizi balita normal $(81,8 \%)$ dan yang memiliki pengetahuan kurang dengan status gizi balita tidak normal (92,9\%) (Puspasari, 2017).

Penelitian ini dilakukan di wilayah Semarang Utara dimana merupakan daerah dengan perekonomian menengah kebawah dan mempunyai pola asuh terhadap balita yang masih minim serta ibu yang memiliki latar belakang pendidikan sekolah dasar dan menengah. Tujuan Penelitian mengetahui hubungan pola asuh makan, tingkat pendidikan, pengetahuan ibu dan pendapatan keluarga dengan status gizi balita.

\section{METODE PENELITIAN}

Penelitian ini menggunakan metode kuantitatif dengan desain penelitian deskriptif menggunakan pendekatan cross sectional untuk mengetahui faktor-faktor yang berhubungan dengan status gizi balita seperti pola asuh dalam pemberian makan, tingkat pendidikan, pengetahuan ibu tentang gizi balita, serta pendapatan keluarga.

Populasi dalam penelitian ini adalah semua ibu yang mempunyai anak dibawah lima tahun (balita) di wilayah Puskesmas Poncol Kota Semarang yang berjumlah 1312 orang. Teknik pe-ngambilan sampel menggunakan pro-portional stratified random sampling dengan sampel sebanyak 89 responden. Uji validitas dilakukan Puskesmas Tlogosari Kulon pada 15 responden pada bulan Mei 2019.

Hasil Uji validitas kuesioner pola asuh makan dari 24 penyataan terdapat 20 
pernyataan yang valid dan kuesioner pengetahuan terdapat 20 penyataan yang valid. Hasil uji validitas diperoleh nilai $r$ hitung masing-masing pernyataan lebih besar dari $r$ tabel $(0,514)$, maka kuesioner yang digunakan dalam penelitian ini dapat dikatakan valid.

Penelitian dilaksanakan pada bulan juni - juli 2019. Analisa data yang digunakan adalah analisa univariat untuk mendeskripsikan faktor-faktor yang berhubungan dengan status gizi balita di Puskesmas Poncol Kota Semarang. Analisa bivariat dilakukan untuk mengetahui hubungan antara stataus gizi dengan pola asuh makan, tingkat pendidikan ibu, pengetahuan ibu dan pendapatan keluarga dengan menggunakan SPSS 21. Uji yang digunakan adalah uji Two-Sample Kolmogorov Smirnov.

\section{HASIL PENELITIAN}

Gambaran umum yang diamati berdasarkan analisis data adalah jenis kelamin balita, umur balita dan jumlah anggota keluarga. Didapatkan hasil bahwa 89 responden diperoleh, seperti dalam tabel ini:

Tabel 1. Karakteristik Responden

\begin{tabular}{|c|c|c|c|}
\hline No & Karakteristik & Jumlah & Persentase \\
\hline \multirow[t]{5}{*}{1} & Status Gizi & & \\
\hline & Gizi Lebih & 3 & $3,4 \%$ \\
\hline & Gizi Baik & 40 & $44,9 \%$ \\
\hline & Gizi Kurang & 44 & $49,4 \%$ \\
\hline & Gizi Buruk & 2 & $2,2 \%$ \\
\hline \multirow[t]{3}{*}{2} & Jenis Kelamin Balita & & \\
\hline & Perempuan & 55 & $61,8 \%$ \\
\hline & Laki-Laki & 34 & $38,2 \%$ \\
\hline \multirow[t]{3}{*}{3} & Usia Balita & & \\
\hline & $12-36$ bulan & 58 & $65,2 \%$ \\
\hline & $37-60$ bulan & 31 & $34,8 \%$ \\
\hline \multirow[t]{3}{*}{4} & Pendidikan Ibu & & \\
\hline & Menengah, Tinggi & 37 & $41,6 \%$ \\
\hline & Dasar & 52 & $58,4 \%$ \\
\hline \multirow[t]{3}{*}{5} & Jumlah anggota keluarga & & \\
\hline & $\leq 4$ anggota keluarga & 62 & $69,7 \%$ \\
\hline & $>4$ anggota keluarga & 27 & $30,3 \%$ \\
\hline \multirow[t]{3}{*}{6} & Pendapatan Keluarga & & \\
\hline & Tinggi & 34 & $38,2 \%$ \\
\hline & Rendah & 55 & $61,8 \%$ \\
\hline \multirow[t]{3}{*}{7} & Pola Asuh Makan & & \\
\hline & Baik & 37 & $41,6 \%$ \\
\hline & Kurang & 52 & $58,4 \%$ \\
\hline \multirow[t]{3}{*}{8} & Pengetahuan & & \\
\hline & Baik & 41 & $46,1 \%$ \\
\hline & Cukup Kurang & 48 & $53,9 \%$ \\
\hline
\end{tabular}


Tabel 1 menunjukkan status gizi lebih sebanyak 3 balita $(3,4 \%)$, gizi baik 40 balita $(44,9 \%)$, gizi kurang 44 balita $(49,4 \%)$ dan gizi buruk 2 balita $(2,2 \%)$. Jenis kelamin balita perempuan sebanyak 55 balita $(61,8 \%)$ dan jenis kelamin balita laki-laki sebanyak 34 balita $(38,2 \%)$. Sebagian besar balita memiliki usia 12-36 bulan sebanyak 58 balita $(65,2 \%)$ dan usia $37-60$ bulan sebanyak 31 balita $(34,8 \%)$. Tingkat pendidikan ibu menengah dan tinggi sebanyak 37 responden $(41,6 \%)$ dan pendidikan dasar sebanyak 52 responden $(58,4 \%)$.

Jumlah anggota keluarga dalam satu tempat tinggal $\leq 4$ anggota keluarga sebanyak 62 responden $(69,7 \%)$ dan > 4 anggota ke-luarga sebanyak 27 responden (30,3\%). Pola Asuh makan baik sebanyak 37 responden $(41,6 \%)$ dan pola asuh makan kurang sebanyak 58,4\%. Pengetahuan ibu baik sebanyak 41 responden $(46,1 \%)$ dan pola asuh kurang serta cukup sebanyak 48 responden $(53,9 \%)$.

Tabel 2. Hubungan Status Gizi Balita dengan Pola asuh, tingkat pendidikan, pengetahuan, pendapatan keluarga

\begin{tabular}{|c|c|c|c|c|c|c|c|c|c|c|c|c|}
\hline \multirow{3}{*}{$\begin{array}{l}\mathrm{N} \\
\mathrm{o}\end{array}$} & \multirow{3}{*}{ Variabel } & \multicolumn{10}{|c|}{ Status Gizi Berdasarkan berat badan menurut Umur } & \multirow{3}{*}{$\begin{array}{c}\mathrm{P} \\
\text { Valu } \\
\mathrm{e}\end{array}$} \\
\hline & & \multicolumn{2}{|c|}{ Buruk } & \multicolumn{2}{|c|}{ Kurang } & \multicolumn{2}{|c|}{ Baik } & \multicolumn{2}{|c|}{ Lebih } & \multicolumn{2}{|c|}{ Total } & \\
\hline & & $\mathrm{n}$ & $\%$ & $\mathrm{n}$ & $\%$ & $\mathrm{n}$ & $\%$ & $\mathrm{n}$ & $\%$ & $\mathrm{n}$ & $\%$ & \\
\hline 1 & Pola Asuh & & & & & & & & & & & \\
\hline & a. Kurang & 1 & 1.9 & 3 & 57. & 20 & 38.5 & 1 & 1.9 & 5 & 10 & 0.411 \\
\hline & b. Baik & 1 & 2.7 & 0 & 7 & 20 & 54.1 & 2 & 5.4 & 2 & 0 & \\
\hline & & & & 1 & 37. & & & & & 3 & 10 & \\
\hline & & & & 4 & 8 & & & & & 7 & 0 & \\
\hline
\end{tabular}

\begin{tabular}{|c|c|c|c|c|c|c|c|c|c|c|c|c|}
\hline \multirow[t]{5}{*}{2} & Pendidikan & & & & & & & & & & & \multirow{5}{*}{0.018} \\
\hline & a. Dasar & 2 & 3.8 & 3 & 61. & 18 & 34.6 & 0 & 0.0 & 5 & 10 & \\
\hline & c. Menengah, & 0 & 0.0 & 2 & 5 & 22 & 59.5 & 3 & 8.1 & 2 & 0 & \\
\hline & \multirow[t]{2}{*}{ Tinggi } & & & 1 & 32. & & & & & 3 & 10 & \\
\hline & & & & 2 & 4 & & & & & 7 & 0 & \\
\hline 3 & Pengetahuan & & & & & & & & & & & \multirow{5}{*}{0.062} \\
\hline & a.Cukup, & 2 & 4.2 & 2 & 60. & 17 & 35.4 & 0 & 0.0 & 4 & 10 & \\
\hline & Kurang & 0 & 0.0 & 9 & 4 & 23 & 56.1 & 3 & 7.3 & 8 & 0 & \\
\hline & \multirow[t]{2}{*}{ b. Baik } & & & 1 & 36. & & & & & 4 & 10 & \\
\hline & & & & 5 & 6 & & & & & 1 & 0 & \\
\hline 4 & Pendapatan & & & & & & & & & & & \multirow{5}{*}{0.000} \\
\hline & a.Rendah & 2 & 3.6 & 3 & 70. & 14 & 25.5 & 0 & 0.0 & 5 & 10 & \\
\hline & \multirow[t]{3}{*}{ b. Tinggi } & 0 & 0.0 & 9 & 9 & 26 & 26 & 3 & 8.8 & 5 & 0 & \\
\hline & & & & 5 & 14. & & & & & 3 & 10 & \\
\hline & & & & & 7 & & & & & 4 & 0 & \\
\hline
\end{tabular}


Berdasarkan hasil uji statistik yang dilakukan dengan uji Two-Sample Kolmogorov Smirnov pada tabel 2 didapatkan nilai $\mathrm{p}<0,05$ pada faktor pola asuh makan $(0,411)$, tingkat pendidikan ibu (0,018), pengetahuan ibu $(0,062)$, pendapatan keluarga $(0,000)$ yang menunjukkan bahwa terdapat hubungan antara tingkat pendidikan ibu dan pendapatan keluarga dengan status gizi balita. Sedangkan tidak terdapat hubungan antara pola asuh makan dan pengetahuan ibu dengan status gizi balita di Puskesmas Poncol Kota Semarang.

\section{PEMBAHASAN}

Hasil penelitian menunjukkan masih ditemukan anak balita yang berstatus gizi kurang sebanyak 49,4\%. Distribusi tersebut menunjukkan bahwa prevalensi gizi buruk dan gizi kurang di wilayah Puskesmas Poncol masih tergolong tinggi dibandingkan dengan target RPJMN 2019 sebesar $17 \%$ balita gizi buruk dan kurang (Kemenkes RI, 2018).

Hasil penelitian menjelaskan bahwa pola asuh makan di Puskesmas Poncol tergolong kurang yaitu sebanyak 52 orang $(58,4 \%)$. Praktik pengasuhan sangat penting untuk me-ngoptimalkan pertumbuhan dan perkembangan fisik dan mental anak. Berdasarkan jawaban pernyataan "Ibu memperbolehkan anak me-ngambil makanannya sendiri" terdapat 40 responden $(44.9 \%)$ yang tidak pernah me-lakukan. Hal ini sebaiknya dilakukan agar anak memiliki kemandirian sejak dini dan ibu tetap melakukan pada anak.

Hasil penelitian menunjukkan tingkat pendidikan ibu di Puskesmas Poncol yaitu pendidikan rendah ( $\mathrm{SD}$ dan SMP ) sebanyak 52 orang $(58,4 \%)$. Pendidikan ibu berperan penting dalam menentukan kondizi gizi pada anak, ibu dengan tingkat pendidikan yang baik dianggap memiliki pengetahuan yang cukup untuk memilih menu yang tepat dan cara pengolahan makanan yang benar bagi anaknya.

Berdasarkan distribusi pengetahuan ibu tentang gizi di Puskesmas Poncol sebagian responden memiliki pengetahuan rendah dan cukup sebanyak sebesar $53.9 \%$. hal ini tampak pada jawaban pernyataan kuesioner indikator ASI dari responden, dimana sebagian besar responden beranggapan bahwa kandungan ASI belum bisa memenuhi gizi balita sehingga kebanyakan responden menjawab salah pada pernyataan ini.

Hasil penelitian didapatkan bahwa dari 89 responden di Puskesmas Poncol sebagian pendapatan keluarga rendah ( dibawah UMR dan tabungan mereka dibawah standar, yaitu sebanyak 55 orang (61,8\%). Hal ini menunjukkan bahwa sebagian besar responden memiliki pendapatan keluarga yang rendah hal ini dapat mempengaruhi status gizi balita, kemungkinan jika pendapatan keluarga tinggi maka daya beli keluarga baik.

Berdasarkan analisis bivariat terdapat tidak terdapat hubungan antara pola asuh makan dengan status gizi balita di Puskesmas Poncol Kota Semarang dengan p value $(0,411)$. Pola asuh kurang secara teori seharusnya mempengaruhi status gizi kurang, tetapi dalam penelitian ini terdapat pola asuh kurang yang mempengaruhi status gizi balita baik. Hal tersebut dapat disebabkan oleh faktor yang lain seperti pengetahuan, pendidikan, pendapatan keluarga.

Hasil Penelitian ini sesuai dengan hasil penelitian yang dilakukan oleh Lusiana Retno menunjukkan bahwa tidak terdapat hubungan antara pola asuh makan dengan 
status gizi balita (Anggono \& Nurrahima, 2015). Karakteristik penelitian tersebut sama dengan penelitian ini yaitu tingkat pendidikan responden rendah serta pendapatan rendah. Pada penelitian yang dilakukan Tiara dwi menunjukkan hasil yang berbeda yakni, terdapat hubungan antara pola asuh makan dengan status gizi balita dengan $\mathrm{p}$ value $(0,014)$, karakteristik responden hampir sama tetapi untuk pekerjaan sebagian besar adalah wiraswasta (Pratiwi, Masrul, \& Yerizel, 2016).

Hasil analisa status gizi berdasarakan tingkat pendididkan ibu diperoleh $\mathrm{p}$ value (0.018), ada hubungan tingkat pendidikan ibu dengan status gizi balita di Puskesmas Poncol Kota Semarang. Ibu yang memiliki pendidikan tinggi akan lebih mudah menerima wawasan yang luas mengenai gizi, mudah menerima perubahan ilmu pengetahuan, sedangkan pendidikan yang rendah menyebabkan keterbatasan dalam memahami tentang kebutuhan gizi anak dan lambat dalam menangani masalah gizi anak.

Hal ini senada dengan hasil penelitian (Sebataraja, Oenzil, \& Asterina, 2014) bahwa Anak dengan ibu berpendidikan rendah memiliki angka mortalitas yang lebih tinggi dibandingkan ibu berpendidikan tinggi. Penelitian Ranityas memiliki karakteristik sama dengan penelitian ini, hasil penelitian tersebut menyatakan adanya hubungan antara tingkat pendidikan ibu dengan status gizi balita (Ranityas, Era, \& Diyah, 2016).

Berdasarkan hasil analisa diketahui bahwa tidak ada hubungan anatara pengetahuan ibu dengan status gizi balita $p$ value (0,062). Tingkat pengetahuan berpengaruh terhadap perilaku dalam memilih makanan yang berdampak pada asupan gizi. Penelitian yang dilakukan oleh Burhani menunjukkan tidak ada hubungan pengetahuan ibu dengan status gizi balita dengan $\mathrm{p}$ value (0.638) (Burhani, Oenzil, \& Revilla, 2016).

Pada penelitian yang dilakukan Nyndina Puspasari menunjukkan hasil yang berbeda yakni terdapat hubungan antara pengetahuan ibu dengan status gizi balita $(\mathrm{BB} / \mathrm{U})$ usia 12-24 bulan dengan $\mathrm{p}$ value $(0,000)$, penelitian tersebut memiliki karakteristik yang sama tetapi didapatkan hasil pengetahuan baik disertai pendidikan ibu yang tinggi (Puspasari, 2017).

Hasil analisa menunjukan bahwa ada hubungan antara pendapatan keluarga dengan status gizi balita dengan $\mathrm{p}$ value (0.000). Hal ini menunjukkan bahwa pendapatan keluarga merupakan faktor yang mempengaruhi status gizi balita. Penelitian yang dilakukan Mulazimah menyatakan bahwa ada hubungan antara pendapatan dengan status gizi balita (Mulazimah, 2017).

\section{KESIMPULAN DAN SARAN}

Hasil penelitian ini menunjukkan bahwa sebagian besar status gizi balita (BB/U) kurang 49,4\%, pola asuh makan kurang $58,4 \%$, tingkat pendidikan ibu dasar (SD,SMP) 58,4\%, pengetahuan ibu kurang dan cukup 53,9\%, serta pendapatan keluarga rendah $61,8 \%$ di Puskesmas Poncol Kota Semarang. Tidak ada hubungan pola asuh makan, pengetahuan ibu dengan status gizi balita di Puskesmas Poncol Kota Semarang. Ada hubungan tingkat pendidikan ibu dan pendapatan keluarga dengan status gizi balita di Puskesmas Poncol Kota Semarang. Hasil penelitian ini dapat menjadi evaluasi untuk dapat mengoptimalkan program pemantauan status masyarakat. 


\section{UCAPAN TERIMA KASIH}

Pada kesempatan ini, peneliti ingin mengucapkan terima kasih kepada berbagai pihak yang telah membantu terwujudnya penelitian ini :

1. Ketua STIKes Karya Husada Semarang

2. Ketua Lembaga Penelitian dan Pengabdian STIKes Karya Husada Semarang

3. Teman sejawat dan para mahasiswa prodi Keperawatan STIKes Karya Husada Semarang

\section{DAFTAR PUSTAKA}

Afritayeni. (2017). Pola pemberian Makan pada Balita Gizi Buruk di Kelurahan Rumbai Bukit Kota Pekan Baru. Journal Endurance, 7-17.

Anggono, L. R., \& Nurrahima, A. (2015). Hubungan Pola Asuh Makan dengan STatus Gizi Anak Balita Dari Ibu Pengrajin Bambu di Desa Kebonsari Kecamatan Borobudur Kabupaten Magelang. Journal UNIMUS , 1-6.

Burhani, P., Oenzil, F., \& Revilla, G. (2016). Hubungan Tingkat Pengetahaun Ibu dan Tingkat Ekonomi Keluarga Nelayan dengan Status Gizi Balita di Kelurahan Air Tawar Barat Kota Padang. Jurnal Kesehatan Andalas, 515-521.

Indah, \& Jayani. (2015). Hubungan Antara Penyakit Infeksi dengan Status Gizi Balita. Java Health Journal , 1-8.

Kemenkes RI. (2018). Hasil Utama Riskesdas 2018. Badan penelitian dan Pengembangan Kesehatan: www.depkes.go.id.
Kemenkes RI. (2015). Situasi Kesehatan Anak Balita di Indonesia. Jakarta: Pusat data dan informasi (Infodatin).

Mulazimah. (2017). Hubungan Pendapatan Keluarga Dengan Status Gizi Balita Desa Ngadiluwih Kecamatan Ngadiluwih Kabupaten Kediri. OJS UNP Kediri, 1821.

Pratiwi, T. D., Masrul, M., \& Yerizel, E. (2016). Hubungan Pola Asuh dengan Status Gizi Balita di Wilayah Kerja Puskesmas Belimbing Kota Padang. Jurnal Kesehatan Andalas , 661-665.

Puspasari, N. (2017). Hubungan Pengetahuan Ibu Tentang Gizi, Tingkat Asupan Makan Balita dan Budaya Pemberian Makan dengan Status Gizi Balita dan Budaya Pemberian Makan dengan Status Gizi Balita (BB/U) Usia 1224 Bulan. Skripsi Thesis Universitas Airlangga .

Ranityas, K., Era, R., \& Diyah, Y. (2016). Hubungan Tingkat Pendidikan Ibu dengan Status Gizi Balita di Puskesmas Pleret. Jurnal Kesehatan , 07.

Sebataraja, L. R., Oenzil, F., \& Asterina, A. (2014). Hubungan Status Gizi dengan Status Sosial Ekonomi Keluarga Murid Sekolah Dasar di Daerah Pusat dan Pinggiran Kota Padang. Jurnal Kesehatan Andalas , 182-187.

Septikasari, M. (2018). Status Gizi Anak dan Faktor Yang Mempengaruhi edisi pertama. Yogyakarta: UNY Press.

Setyawati, V., \& Hartini, E. (2018). Buku Ajar Dasar Ilmu Gizi Kesehatan Masyarakat. Yogyakarta: Deepublish. 
World Health Organization. (2018). Levels

and Trends in Child Malnutrition. WHO :

www.who.int. 